\title{
Odrobina krytycznego dystansu. Historia środowiska na temat debaty o antropocenie ${ }^{1}$
}

Tytul: The Shock of the Anthropocene. The Earth, History and Us

Autorzy: Christophe Bonneuil, Jean-Baptiste Fressoz

Przełożyl: David Fernbach

Wydawca: Verso

Rok wydania: 2016

Liczba stron: 320

\section{Ewa Bińczyk}

Instytut Filozofii

Uniwersytet Mikołaja Kopernika w Toruniu

Ewa.Binczyk@umk.pl

Przyjęto: 15 luty; zaakceptowano: 27 luty.

W 2016 roku przełożono na język angielski książkę historyków środowiska, Christophe’a Bonneuila i Jeana-Baptiste’a Fressoz, Szok antropocenu: Ziemia, historia i my. Oryginalnie została ona opublikowana po francusku w 2013 roku. To wyjątkowa pozycja pod wieloma względami. Zdecydowanie warta uwagi. Wpisuje się $\mathrm{w}$ intensywnie prowadzoną od ponad dekady debatę na temat antropocenu. Biorą w niej udział zarówno przyrodoznawcy (geolodzy, badacze nauki o systemie Ziemi - Earth system science, klimatolodzy, geografowie społeczni), jak i humaniści (historycy środowiska, socjologowie, filozofowie, ekonomiści, badacze zrównoważonego rozwoju). Dyskusja ta ma niezwykle interesujący wydźwięk filozoficzny i odsłania wiele paradoksów. Przede

\footnotetext{
${ }^{1}$ Tekst został przygotowany w ramach realizacji grantu Narodowego Centrum Nauki (nr rejestracyjny projektu 2016/21/B/HS1/00829, tytuł projektu: Retoryka środowiskowa i marazm antropocenu. Analiza dyskursów).
} 
wszystkim wydarzenia, które skłaniają badaczy do tego, by nową epokę geologiczną nazwać antropocenem, świadczą zarówno o ludzkiej potędze - hipersprawczości, jak i wielowymiarowej bezradności, bezsilności (zob. Bonneuil, Fressoz, 2016, ss. xi, 24). Recenzowana monografia świetnie to uwypukla.

Słowa kluczowe: antropocen; Ziemia; historia środowiska

Debatę o antropocenie zapoczątkowali nieżyjący już biolog Eugene F. Stoermer oraz holenderski badacz atmosfery Paul J. Crutzen (laureat Nagrody Nobla z 1995 roku w dziedzinie chemii). W tekście z 2000 roku zasugerowali oni, by współczesną epokę geologiczną nazwać „epoką człowieka” - „antropocenem” (Crutzen, Stoermer, 2000). Ich zdaniem człowiek jako gatunek stał się supersprawczą siłą o znaczeniu geologicznym. Świadczy o tym między innymi to, że przekraczamy tak zwane granice planetarne (planetary boundaries). Chodzi o parametry gwarantujące stabilność dla życia epoki holocenu, będące zarazem warunkiem przetrwania ludzkości na Ziemi (Rockström i in., 2009). Najgroźniejsze w tym kontekście procesy dotyczą obecnie zmiany klimatycznej, degradacji gleb, zakwaszenia oceanów, zaburzenia cykli biogeochemicznych Ziemi (to znaczy obiegu azotu i fosforu) i tempa utraty bioróżnorodności (tak zwane szóste wielkie wymieranie gatunków).

Jak sądzę, możemy dziś mówić o niespotykanym medialnym sukcesie propozycji Crutzena i Stoermera. Debata na temat antropocenu zainspirowała wielu naukowców, intelektualistów i artystów. Wyszukiwarka Google pokazuje dziś ponad 2 miliony stron internetowych zawierających hasło „Anthropocene” (stan na 20.01.2018). Natomiast w bazie czasopism Sage journals znajdziemy ponad 600 artykułów zawierających to hasło w tytule (stan na 26.09.2017).

Na podstawie najważniejszych publikacji interdyscyplinarnego czasopisma „The Anthropocene Review”2 oraz monografii badawczych, które ukazały się w ostatnich latach (Hamilton, Bonneuil, Gemenne, 2015; Moore, 2016; Angus, 2016; Hamilton, 2017) możemy wskazać najważniejsze rodzaje narracji w akademickiej debacie na temat antropocenu. Należą do nich: 1) naturalistyczna narracja przyrodoznawców (z tekstami autorów takich jak E. Stoermer, P. Crutzen, W. Steffen, J. Zalasiewicz, J. Röckstrom), 2) narracja humanistów odwołujących się do pojęć postprzyrody, Gai, posthistorii (D. Haraway, B. Latour, I. Stengers, D. Chakrabarty), 3) dyskurs eko-marksistowski, operujący etykietką kapitalocenu, zdecydowanie krytyczny wobec etykietki antropocenu (J. Moore, I. Angus, A. Hornborg, A. Malm), 4) dyskurs eko-katastroficzny (C. Hamilton, E. Crist, J. McBrien), a także 5) narracja ekomodernistów mówiąca o dobrym, a nawet wspaniałym antropocenie, w którym dzięki rozwiązaniom takim jak

${ }^{2}$ Jest to czasopismo naukowe poświęcone wyłącznie tematyce antropocenu, wydawane przez Sage Publications. Źródło: https://uk.sagepub.com/en-gb/eur/journal/anthropocene-review. Dostęp 20.01.2018. 
geoinżynieria zamienimy Ziemię w „planetarny ogród”, z którego „będziemy dumni” (T. Nordhaus, M. Schelleberger, D. W. Keith).

Niestety, nie ma tu miejsca na szczegółową dyskusję wymienionych wyżej dyskursów3 ${ }^{3}$ Warto jednak zaznaczyć, że książka Bonneuila i Fressoz doskonale wpisuje się w najnowsze dyskusje na temat antropocenu, rekapitulując je, systematyzując, a także eksponując ich słabości. Co jednak najważniejsze, analizy francuskich historyków środowiska pomagają nam wyrobić własną krytyczną opinię na temat wybranych motywów debaty o antropocenie.

Książka Szok antropocenu została podzielona na trzy części (jedenaście rozdziałów). Rozdział pierwszy przedstawia naturalistyczną narrację przyrodoznawców na temat antropocenu. Badacze Ziemi podkreślają, że działania człowieka zaburzają funkcjonowanie systemów planetarnych: atmosfery, litosfery, hydrosfery i poszczególnych ekosystemów. W omawianym typie narracji dominują pojęcia takie jak: kryzys planetarny, załamanie linearności, punkt krytyczny/przełomowy, przekroczenie wartości progowej, nieodwracalność, nieprzewidywalność, utrata czasu (przekonanie, że jest już za późno), bezprecedensowość, utrata natury, ryzyko zapaści systemowej, nieznana przyszłość, wytrącenie z równowagi. Do dalszych szczegółów narracji badaczy science za chwilę powrócimy.

Rozdział drugi Myśląc razem z Gaja - w stronę humanistyki środowiskowej ukazuje wpływ debaty na temat antropocenu na nauki humanistyczne i społeczne. W obręb wspomnianej wyżej, dynamicznie rozwijającej się dziś humanistyki środowiskowej wchodzą między innymi: ekologia polityczna, ekologiczna ekonomia, antropologia i historia źródeł energii, historia środowiska, socjologia środowiska, prawo i etyka środowiskowe. Idea antropocenu ma wyjątkowy potencjał. Przychylam się do tezy Bonneuila i Fressoz głoszącej, że debata sprowokowana pojęciem antropocenu to wydarzenie o znaczeniu filozoficznym i politycznym. Dokonujące się na naszych oczach przekraczanie kolejnych granic planetarnych wymusza ponowne przemyślenie samej kondycji człowieczeństwa. Ma to niezbywalny wymiar egzystencjalny, a nawet eschatologiczny ${ }^{4}$. Równocześnie przyrodoznawcy ostrzegają, że destabilizacja klimatu spowoduje dalsze drastyczne straty dla rolnictwa, zniszczenie infrastruktur i systemów bezpieczeństwa, straty sektora ubezpieczeń i całej gospodarki. Czeka nas nowa przyszłość polityczna, naznaczona konfliktami o skali globalnej. Jak czytamy w książce Szok antropocenu: „ludzie będą umierać, a kraje znikać” (Bonneuil, Fressoz, 2016, s. 24).

\footnotetext{
${ }^{3}$ Piszę na ich temat więcej w książce Epoka człowieka. Retoryka i marazm antropocenu, która ukaże się w 2018 roku nakładem Wydawnictwa Naukowego PWN.

${ }^{4}$ Szczególnie z uwagi na powracające w debacie przekonanie, że żyjemy „u kresu czasu”, nasza sytuacja jest „bez precedensu”, a położenie i decyzje polityczne obecnego pokolenia mają wyjątkowe znaczenie dla historii gatunku homo sapiens na Ziemi.
} 
Jak przekonują francuscy historycy środowiska, jeśli człowiek stał się „siłą o znaczeniu geologicznym” kształtującą planetę, dualistyczne rozróżnienie przyrody i społeczeństwa traci sens. Procesy społeczno-polityczne zostały zintegrowane z procesami naturalnymi. Co więcej wprowadzenie i utrzymywanie dualizmu przyroda-społeczeństwo $\mathrm{z}$ dzisiejszej perspektywy okazuje się szkodliwe. Separując społeczeństwo od przyrody nowożytne nauki humanistyczne zignorowały bowiem ważne tematy: metabolizmu społecznoekologicznego, wymiany materii oraz energii między wsią a miastem (a także między kontynentami), problematykę żyzności gleb, cyrkulacji wód i powietrza (Bonneuil, Fressoz, 2016, s. 32).

W epoce antropocenu dyskutujemy już o postprzyrodzie i żyjemy w czasach postśrodowiskowych. Zamiast zewnętrznego względem naszym działań środowiska, do którego mogliśmy delegować niechciane ich skutki (takie jak odpady i zanieczyszczenia), dyskutanci w debacie na temat antropocenu koncentrują się na ściśle zintegrowanych systemach planetarnych, na ograniczeniach Ziemi ujmowanej holistycznie. Gatunek homo sapiens jest w tym podejściu elementem destabilizującej się na naszych oczach, zunifikowanej całości. Mówimy tu o splątanych sieciach powiązań, wzajemnie oddziałujących na siebie aspektach systemów planetarnych: „postaw konsumenckich Europejczyków i orangutanów w Indonezji, rynków i lasów deszczowych, nierówności społecznych i zakłóceń hormonalnych” (Bonneuil, Fressoz, 2016, s. 35).

Wystąpienie pojęć postnatury w debacie na temat przekraczania granic planetarnych nie oznacza jednak całkowitego wyeliminowania czy zignorowania sprawczości przyrody. Wręcz przeciwnie, problemy, na których koncentruje się omawiana dyskusja, takie jak ryzyko katastrofy klimatycznej, rozpowszechnianie się martwych, pozbawionych tlenu stref w oceanach, roztopienie się wiecznej zmarzliny syberyjskiej czy załamanie procesów zapylania, to tylko symptomy ponownego „wtargnięcia Gai” ${ }^{5}$ w horyzont działań człowieka.

Omawiany rozdział przedstawia całą gamę niebagatelnych dla nauk humanistycznych i społecznych konsekwencji dyskusji na temat antropocenu. Przede wszystkim okazuje się, że potrzebujemy redefinicji pojęcia wolności. Jak dotąd projekt emancypacji człowieka koncentrował się na możliwościach zapanowania nad fatalizmem sił przyrody. Jednakże nowy, postśrodowiskowy ideał emancypacji musi zakładać wzmożoną ostrożność, przezorność i poszerzoną odpowiedzialność. W dobie kryzysu planetarnego i wielkiego wymierania gatunków nie możemy abstrahować od przyrody ani tym bardziej emancypować się od niej. Musimy zacząć myśleć „razem z Gają” (Bonneuil, Fressoz, 2016, s. 41).

${ }^{5}$ Wtargnięcie Gai (intrusion of Gaia) to pojęcie ukute przez belgijską filozofkę, Isabelle Stengers (Stengers, 2009). 
Co więcej w XXI wieku nie można już liczyć na zobiektywizowane, scjentystyczne czy stymulowane rynkowo równoważenie rozwoju. „Zielony wzrost” okazał się pojęciem wewnętrznie sprzecznym. Dalsze promowanie wzrostu gospodarczego nie powinno być naszym celem na planecie o dramatycznie kurczących się zasobach, której grozi wejście w epokę poważnych zakłóceń oraz anomalii (por. Jackson, 2015). Z tego właśnie powodu neoliberalna retoryka wyceniania tak zwanych „usług ekosystemowych”, analizy kosztów i korzyści, „banków ekosystemowych” powinna zostać odrzucona ${ }^{6}$.

Ponadto $\mathrm{w}$ epoce antropocenu nie można już dłużej rozpatrywać relacji władzy, nie biorąc pod uwagę problemów ekologii. Naszym centralnym pojęciem politycznym powinno się stać pojęcie reżimu materialno-energetyczno-społecznego (Bonneuil, Fressoz, 2016, ss. 36-37). Drastyczna dekarbonizacja gospodarek, która czeka ludzkość z uwagi na ryzyko destabilizacji klimatu to wyzwanie bez precedensu. Zasady bezpieczeństwa energetycznego, priorytety gospodarcze, systemy podatkowe i międzynarodowe prawo handlowe muszą zostać zaprojektowane na nowo. Zdaniem Bonneuila i Fressoz, w świecie, w którym mit postępu utożsamionego z nieograniczonym wzrostem materialnym okazuje się irracjonalny, musimy też na nowo przemyśleć podstawowe założenia demokracji. Ludzkości w XXI wieku nie uda się podtrzymać dawnych, modernistycznych obietnic dotyczących konsumpcji, inwestycji i eksploatacji. Oznacza to poważne wyzwanie dla naszego myślenia o pożądanym ładzie politycznym.

Rozdziały trzeci i czwarty Szoku antropocenu składają się na drugą, krytyczną w swej wymowie część recenzowanej monografii. Autorzy dokonują tutaj dekonstrukcji wybranych, szkodliwych w ich mniemaniu motywów debaty na temat antropocenu występujących w tekstach badaczy science. Choć zdaniem Bonneuila i Fressoz warto upowszechniać samo pojęcie antropocenu, to jednak dominująca narracja przyrodoznawców na temat epoki człowieka jest z kilku powodów problematyczna (zob. Bonneuil, Fressoz, 2016, s. 94). Przyjrzyjmy się tym powodom bliżej.

Przede wszystkim Bonneuil i Fressoz nieufnie podchodzą do „geokratycznego” wymiaru dyskusji o antropocenie. Postrzega się tu Ziemię jako system „widziany znikąd”. Zdaniem francuskich historyków, dyskurs badaczy science (prawdopodobnie nieintencjonalnie) przybiera postać hegemonicznej, unifikującej opowieści na temat Ziemi jako obiektu, który może podlegać kontroli i naukowemu zarządzaniu. W szczególności dotyczy to artykułów Paula Crutzena, Willa Steffena, Jana Zalasiewicza, Johana Röckstroma i Roberta Constanzy (Bonneuil, Fressoz, 2016, s. 48).

\footnotetext{
${ }^{6}$ Niestety, jest to retoryka wciąż dominująca w programach ochrony środowiska czy też programach Unii Europejskiej, takich jak Horizon 2020.
} 
Bonneuil i Fressoz zwracają uwagę, że w tekstach przyrodoznawców mowa jest o „ewolucji gatunku ludzkiego”, który w naturalny sposób dąży do antropopresji, zawłaszczając coraz większe obszary planety (por. Steffen, Crutzen, McNeill, 2007). Historię wzrostu społeczeństw i Wielkiego Przyspieszenia po II wojnie światowej przedstawia się tutaj tak, jakby nie istniały alternatywy. Tekst The Anthropocene: Conceptual and Historical Perspectives (Steffen i in., 2011) wprowadza na przykład narrację na temat kolejnych stadiów ewolucji człowieka na planecie. Zakłada się tu linearną ścieżkę nieuniknionego „rozwoju”, od którego nie mogło być odstępstw. Jest to podejście, które pozwala naturalizować i odpolityczniać namysł nad współczesnym kryzysem środowiskowym. Chodzi o to, że ukazywanie zjawiska rosnącej antropopresji jako efektu naturalnej ewolucji gatunku homo sapiens w szkodliwy sposób odciąga nas od namysłu nad uwarunkowaniami historycznymi epoki, w której się znaleźliśmy. Nie dyskutując z kolei kwestii politycznych, ignorujemy to, że odpowiedzialność za nieodwracalną degradację systemów planetarnych, która przywiodła nas do trudnego położenia antropocenu jest przecież skrajnie nierówno rozłożona - nie tylko z perspektywy historycznej, ale też współczesnej ${ }^{7}$.

Ponadto narracje badaczy science są pod pewnymi względami aroganckie. Podkreśla się tutaj, że człowiek dorównuje innym wielkim siłom przyrody, a pozostawiony przez niego ślad planetarny będzie widoczny przez kolejne miliony lat. W opinii Bonneuila i Fressoz zakłócanie systemów planetarnych przez człowieka nie do końca jest przedstawiane jako katastrofa. Widać tu dumę ze sprawczości i skali wpływu, którą osiągnęliśmy (Bonneuil, Fressoz, 2016, s. 65).

Rozdział czwarty poddaje krytyce również zawartą w dyskursie przyrodoznawców wizję ludzkości jako jednolitego, monolitycznego gatunku. Utrudnia ona wzięcie pod uwagę różnic społeczno-kulturowych oraz politycznych. Jest to zarazem obraz inercyjnych społeczeństw, które w swej anonimowej masie zawiadywane są przez naukowców i twórców zbawczych technologii. Naukowcy są tu ukazani jako bohaterska elita. Mamy wierzyć, że choć politycy nas zawiedli, nauka i inżynieria ocalą ludzkość. Tego typu paternalistyczne myślenie jest jednak w opinii Bonneuila i Fressoz bardzo niebezpieczne, otwiera ono bowiem drogę retorycznym argumentom na rzecz technokratycznych rozwiązań problemu klimatycznego. Kwintesencją podejścia technokratycznego jest promowanie ryzykownych rozwiązań problemu klimatycznego takich jak geoinżynieria ${ }^{8}$. Szczególne chodzi tu o „plan awaryjny" rozpraszania siarki $\mathrm{w}$ stratosferze, uznawany dziś za projekt najtańszy, możliwy do zrealizowania, stanowiący „mniejsze zło”. Jest on bardzo

\footnotetext{
${ }^{7}$ Badania pokazują, że za wyemitowanie $63 \%$ całości emisji $\mathrm{CO}_{2}$ i $\mathrm{CH}_{4}$ w latach 1854-2010 odpowiedzialnych jest około 90 wielkich korporacji (Heede, 2014).

8 Innego typu rozwiązaniem technokratycznym jest biologia syntetyczna, ukazywana jako rozwiązanie dla problemu utraty bioróżnorodności (Bonneuil, Fressoz, 2016, s. 81).
} 
poważnie dyskutowany (por. Bińczyk, 2015). Towarzyszy temu wątpliwa etycznie retoryka „zarządzania planetą Ziemia”. Inżynierię klimatu wspierają tak zwani ekomoderniści, zwolennicy idei dobrego antropocenu (Caradonna $\mathrm{i}$ in., 2015).

Francuskim historykom środowiska zdecydowanie nie podoba się też motyw „wielkiego przebudzenia” w debacie na temat antropocenu. Chodzi o to, że narracja przyrodoznawców sugeruje, iż niezbędną refleksyjność środowiskową ludzkość uzyska dopiero dzięki dyskusji o antropocenie sprowokowanej przez odkrycia naukowców z obszaru nauki o systemie Ziemi (Bonneuil, Fressoz, 2016, s. 73). Jak jednak podkreślają autorzy książki Szok antropocenu, Crutzen, Zalasiewicz i Steffen nie są pierwszymi, którzy podejmują refleksję na temat zatrważającej skali zniszczeń dotyczących środowiska. Intelektualiści XVIII i XIX wieku także ostrzegali przed tym, że działanie człowieka w epoce przemysłowej zmienia planetę, zaburza „harmonię świata”, homo sapiens zaś stał się „potęgą planetarną” (por. Bonneuil, Fressoz, 2016, s. 4). Ludzkość była też określana „siłą geologiczną” w latach 40 . XX wieku przez pisarzy takich jak Henry F. Osborn czy Wiliam Vogt.

Mimo to przyrodoznawcy piszą tak, jakby burzliwa historia obywatelskich protestów przeciwko niszczeniu środowiska w ogóle nie miała miejsca, podobnie jak działania na rzecz realnego (a nie prorynkowego) równoważenia rozwoju, w tym praktyki i refleksja ekonomiczna dotyczące tak zwanego postwzrostu $^{10}$. Możliwe, że naukowcy piszący o antropocenie $\mathrm{w}$ XXI wieku świadomie zignorowali wiedzę historyczną, chcąc podnieść znaczenie i prestiż toczonej współcześnie debaty. Jednak najsmutniejsze jest właśnie to, że ludzkość całkiem świadomie degraduje planetę, pomimo istniejącej już, rozbudowanej refleksji na temat irracjonalności tego typu działań (por. Bonneuil, Fressoz, 2016, s. 78) ${ }^{11}$.

Co ciekawe, Bonneuil i Fressoz przekonują, że dwudziestowieczna myśl prośrodowiskowa bardzo mocno inspirowana była rozwojem projektów militarnego podboju przestrzeni kosmicznej ${ }^{12}$. Świadczy o tym między innymi obecność idei „statku kosmicznego Ziemia” oraz symbolu Błękitnej Planety (sfotografowanej z kosmosu) w refleksji na temat ochrony środowiska. Koncepcje Jamesa Lovelocka, bez których nie byłoby nauki o systemie Ziemi

\footnotetext{
${ }^{9}$ Jak podkreślają francuscy badacze, jest to idea, która wystąpiła już w raporcie Gro Harlem Brundtland Our Common Future (Brundtland, 1987; por. Bonneuil, Fressoz, 2016, s. 90).

${ }^{10}$ Koncepcje postwzrostu (ang. degrowth) ekonomistów takich jak Nicholas Georgescu-Roegen, Jacques Grinevald czy Serge Latouche wpisują się w tradycję wspominanej wyżej, rozwijającej się od lat 80. XX wieku, ekonomii ekologicznej. Ma ona wymiar normatywny, uwzględnia wartości sprawiedliwości i równości międzypokoleniowej oraz nieodwracalność procesów degradacji środowiska. Dziedzina ta bada koewolucję systemów naturalnych oraz gospodarki. Zakłada ona wymóg ochrony kapitału naturalnego.

${ }_{11}$ Zdaniem francuskich badaczy świadczy to o swego rodzaju schizofrenicznym aspekcie nowoczesności (Bonneuil, Fressoz, 2016, s. 196, 197).

${ }^{12} \mathrm{Na}$ ten sam temat zob. też Olson, Messeri, 2015.
} 
(zakładającej cybernetyczną wizję planetarnych sprzężeń zwrotnych), to nic innego jak efekt badań prowadzonych w ramach tak zwanego kompleksu militarno-przemysłowego podczas zimnej wojny. To właśnie wtedy powstały sieci satelitarne, stacje pomiarowe, planetarne i kosmiczne infrastruktury badawcze, dzięki którym potrafimy dziś rozpoznać skalę problemów środowiskowych takich jak zmiana klimatu. Zarówno Lovelock, jak i James Hansen dwie bardzo ważne postaci namysłu na temat granic planetarnych - to byli pracownicy NASA. Militarne projekty podboju kosmosu pozwoliły wykuć „spojrzenie znikąd” na planetę Ziemię jako jedną z wielu planet w kosmosie. Przyczyniły się one do decentralizacji naszej ziemskiej perspektywy. Zrozumieliśmy dzięki nim, że równowaga Błękitnej Planety może okazać się niezwykle delikatna, wrażliwa na zakłócenia (Bonneuil, Fressoz, 2016, ss. 56-64).

Rozwiązaniami opracowywanymi dla potrzeb wojska były wcześniejsze projekty modyfikowania pogody (w tym technologii wywoływania opadów przy użyciu jodku srebra) (por. Fleming, 2010). Jak trafnie zauważają francuscy myśliciele, projekty omawianego typu uzasadniano istnieniem jakiegoś „stanu wyjątkowego" (Bonneuil, Fressoz, 2016, s. 92). Dziś takim stanem wyjątkowym, legitymizującym geoinżynieryjne rozpraszanie siarki w stratosferze okazuje się ryzyko zmiany klimatycznej.

Kolejne rozdziały recenzowanej książki (od piątego do jedenastego) składają się na jej ostatnią część. Pokazują one, jakie warte uwagi procesy historyczne, począwszy od XVIII wieku do dziś ukształtowały antropocen. Były to: 1) polityka energetyczna odpowiedzialna za postępujące emisje $\mathrm{CO}_{2}$ (mówi o niej rozdział piąty - Termocen), 2) militarna historia świata (opisana $\mathrm{w}$ rozdziale szóstym - Tanatocen), 3) narodziny i kształtowanie się społeczeństwa konsumpcyjnego (rozdział siódmy - Fagocen), 4) historia namysłu i refleksji środowiskowej (rozdział ósmy - Fronocen), 5) denializm i ignorowanie problemów planetarnych (rozdział dziewiąty - Agnotocen), 6) historia kapitalizmu (rozdział dziesiąty - Kapitalocen) i wreszcie 7) burzliwa historia społecznego oporu wobec szkód, które niósł ze sobą industrializm (rozdział jedenasty - Polemocen). Zaznaczmy, że Bonneuil i Fressoz nie są jedynymi, którzy proponują alternatywne etykietki wobec terminu „antropocen”. Za każdym razem pozwala to postawić w centrum uwagi inne, wybrane problemy społeczno-polityczne XX i XXI stulecia ${ }^{13}$.

Wspomniane rozdziały to prawdziwa gratka dla Czytelniczki, która chciałaby zrozumieć szersze, systemowe uwarunkowania współczesnego kryzysu planetarnego. Rozdział piąty ukazuje historię termocenu. Jak do tego doszło, że nie widzimy alternatyw wobec dalszego spalania paliw kopalnych? Historia

\footnotetext{
${ }^{13}$ Do takich alternatywnych nazw należą między innymi: anglocen (inna propozycja Fressoz), chtulucen (pomysł D.J. Haraway), kapitalocen (pomysłodawców A. Malma i J. W. Moore’a), mantropocen (propozycja K. Raworth), mizantropocen (idea R. Patela), nekrocen (J. McBrien), oligantropocen (pomysł E. Swyngedouwa), plantacjocen (ponownie D.J. Haraway), plastikocen czy wreszcie technocen (koncept A. Hornborga).
} 
dotychczasowego korzystania ze źródeł energii może nas wiele nauczyć. Pokazuje ona na przykład, że transformacje energetyczne społeczeństw zawsze odbywały się stopniowo, niekoniecznie postępując linearnie (Bonneuil, Fressoz, 2016, s. 101). Często obserwowaliśmy powroty do wcześniejszych źródeł energii, a także zróżnicowane ich wykorzystanie przez poszczególne klasy społeczne. Niektóre „postępowe” technologie energetyczne u swych początków okazywały się nieefektywne, a nawet niebezpieczne ${ }^{14}$. Jak się okazuje, przeceniamy znaczenie kolei dla ekspansji ekonomicznej Stanów Zjednoczonych pod koniec XIX wieku. Nie doceniamy natomiast kluczowej roli dziewiętnastowiecznego transportu rzecznego czy konnego w Europie oraz USA, podobnie zresztą jak roli młynów wodnych.

Paliwa kopalne wcale nie przyjmowały się automatycznie, mieliśmy raczej do czynienia z całą mnogością alternatyw. Historia energii pozwala $\mathrm{z}$ dystansem patrzeć na współczesną dominację ropy, węgla i gazu ziemnego. Określone rozwiązania energetyczne wdrażano często dzięki agresywnemu marketingowi i celowej polityce gospodarczej państw. Nie musiały to być wybory optymalne społecznie ani ekonomicznie.

Kolejny rozdział mówi o militarnym „tanatocenie”. Zdaniem Bonneuila i Fressoz, nie byłoby dramatycznych problemów środowiskowych XXI wieku, gdyby nie logika wojny. Argumentują oni między innymi, że flota brytyjska odegrała fundamentalną rolę $\mathrm{w}$ procesie globalizacji węgla - sprawne funkcjonowanie Imperium Brytyjskiego wymagało istnienia sieci kopalń i łańcucha dostaw. Kontrakty przemysłu zbrojeniowego wielkich krajów, takich jak Francja stabilizowały wielkie inwestycje przemysłu górniczego. W XX wieku sektor wojskowy stopniowo integrował się z przemysłem naftowym. Już I wojnę światową postrzegano jako zwycięstwo ropy (ciężarówek) nad węglem (lokomotywami). Nie byłoby Wielkiego Przyspieszenia (wynikającego z industrializacji i zacieśniania się międzynarodowych relacji handlowych po II wojnie światowej), gdyby nie wielka mobilizacja przemysłu na potrzeby wojny. Wystarczy zauważyć, że podczas II wojny światowej przeciętny żołnierz amerykański konsumował 228 razy tyle energii, co jego poprzednicy (Bonneuil, Fressoz, 2016, s. 144-145). Dokonano wówczas w Stanach Zjednoczonych wielkich inwestycji w rurociągi oraz rafinerie zapewniające dostawy paliwa dla armii, głównie lotnictwa. Współczesny transport lotniczy to nic innego, jak pozostałość tego typu inicjatyw. Pojawienie się w latach 80. XX wieku kontenerów i kontenerowców również ściśle wiąże się z historią konfliktów zbrojnych. Logistyka globalnych przedsięwzięć wojennych opierała się na wykorzystaniu

${ }^{14}$ Dotyczyło to na przykład oświetlenia gazowego w Londynie wprowadzonego na początku XIX wieku. 
transportu towarów na dalekie odległości. Współcześnie transport ten w znaczący sposób przyczynia się do emisji gazów cieplarnianych ${ }^{15}$.

W opinii Bonneuila i Fressoz, gdyby nie II wojna światowa, nie mielibyśmy z kolei podstaw pozwalających stworzyć społeczeństwo masowej konsumpcji. Opowiada o nim rozdział siódmy - Fagocen. Fagocen to epoka fetyszyzmu towarowego, przemysłu reklamowego, planowanej przestarzałości produktów, ostentacyjnego konsumowania i zalewu śmieci. Francuscy historycy podkreślają jednak, że krytyka konsumpcjonizmu jest tak dawna, jak samo to zjawisko. Już w latach 20. zeszłego stulecia krytykowano na przykład planowaną przestarzałość (Bonneuil, Fressoz, 2016, s. 149). Badania historyczne uczulają jednak, że priorytetem obywateli nie zawsze było konsumowanie dóbr. W XX wieku mieliśmy na przykład do czynienia z licznymi strajkami robotników domagających się czasu wolnego i zachowania tradycji wolnych poniedziałków (Bonneuil, Fressoz, 2016, s. 153).

Dwudziestowieczne umasowienie rynków i ich globalizacja sprawiły, że towary stawały się coraz bardziej abstrakcyjne. Ich miejsce pochodzenia przestało być widoczne. Rozpoczęła się era marek, logo. Ochrona znaków towarowych została ustanowiona w 1890 roku w USA. W latach 20. zeszłego stulecia inwazja reklam w przestrzeń publiczną „uświadomiła” obywatelom, że posiadają szereg nowych potrzeb dotyczących higieny, estetyki, wyżywienia, czasu wolnego, urody, ciała oraz zdrowia. Powstała wówczas instytucja kredytu konsumenckiego, będącego nową formą kontroli społecznej (Bonneuil, Fressoz, 2016, ss. 157, 164) ${ }^{16}$. Oprócz sektora reklamy rozwinął się przemysł modowy. Nastała epoka opakowań i tego, co jednorazowe. W latach 50. XX wieku w USA postawiono na rozwój przedmieść i przemysłu motoryzacyjnego. Dzięki upowszechnieniu się telewizji nastąpiły procesy prywatyzacji rozrywki i dalszej indywidualizacji konsumentów. Obywatele zaczęli dojeżdżać do pracy ze swoich domów na kredyt, nie kontaktując się już ze sobą w gęsto zaludnionych centrach miast. Podupadł wówczas transport publiczny, a powierzchnia kraju została pokryta autostradami oraz parkingami. Całkowite odmaterializowanie myślenia o gospodarce nastąpiło dzięki upowszechnieniu wskaźnika PKB. Nieograniczona intensyfikacja transakcji monetarnych stała się celem samym w sobie, bez względu na jej koszty środowiskowe. Praca domowa i praca opiekuńcza stały się wówczas niewidzialne dla teorii ekonomicznych (Bonneuil, Fressoz, 2016, s. 215).

W rozdziale ósmym czytamy o fronocenie - epoce refleksyjności środowiskowej. Jak bowiem argumentują Bonneuil i Fressoz, pojęcia i debaty charakteryzujące XVIII i XIX wiek świadczą o tym, że już wówczas istniała „potoczna

${ }^{15}$ Gdyby transport międzynarodowy rozpatrywać jako kraj, byłby to szósty kraj na świecie emitujący najwięcej gazów cieplarnianych, po Japonii. To więcej niż emisje całej Afryki (Angus, 2016, s. 167). Wysokoemisyjne jest nie tylko przewożenie towarów, ale również ich pakowanie i chłodzenie, a także przetwarzanie (np. żywności).

${ }^{16}$ Do 1957 roku aż 2/3 Amerykanów posiadało już kredyt. 
środowiskowa przyzwoitość". Chodzi o przekonanie, że powinniśmy unikać degradacji przyrody, które wiązało się z pewnymi zwyczajowo przyjmowanym regułami postępowania (Bonneuil i Fressoz, 2016, s. 172). W krajach Europy w omawianym okresie krytykowano gałęzie gospodarki takie jak przemysł farbiarski czy branżę produkcji świec za to, że szczególnie zanieczyszczają one środowisko. Formułowano również obawy dotyczące wyczerpywania się łowisk (Bonneuil, Fressoz, 2016, s. 181). W debacie na temat skutków wylesiania uznawano zmiany klimatyczne za nieodwracalne. Przedstawiano nawet węgiel jako źródło zielonej energii, które pozwoli odtworzyć zasoby leśne (Bonneuil, Fressoz, 2016, s. 201). Podejmowano refleksję na temat racjonalnego zarządzania lasami (pisał o tym między innymi Charles Fourier), rozpatrywano negatywne hydrologiczne efekty deforestacji ${ }^{17}$. Ponieważ Europa zmagała się z problemem wzrostu cen drewna, krytykowano monokulturową uprawę drzew z uwagi na ryzyko zniszczeń wywołanych przez pasożyty czy pogodę. Rozważano również cykle metabolizmu, problem degradacji gleb i ich nawożenia. Dyskusje dotyczyły ewentualnego wyczerpania się zasobów węgla, a także cynku i miedzi, istotnych dla przemysłu telegraficznego.

Rozdział dziewiąty został poświęcony agnotocenowi. Chodzi o epokę, w której produkuje się wątpliwości i niewiedzę. Wiedza dotycząca szkodliwości pewnych działań czy produktów wymaga w takim kontekście zignorowania. Autorzy mówią o agnotocenie, bowiem agnotologia to dziedzina zajmująca się badaniem wytwarzania ignorancji. Chodzi o kampanie dezinformacyjne, polegające na celowej produkcji wątpliwości wobec tez mówiących o szkodliwości azbestu, DDT, palenia tytoniu, kwaśnych deszczy, dziury ozonowej czy ocieplenia klimatu (por. Oreskes, Conway, 2010; Bińczyk, 2013).

Bonneuil i Fressoz podkreślają, że kapitalizm paliw kopalnych wymaga wiary w możliwość niekończącego się rozwoju i nieograniczonego wzrostu PKB. Problem granic wzrostu czy granic planetarnych musi być $\mathrm{w}$ takim modelu przesunięty na margines. Z tego powodu autorzy słynnego raportu Granice wzrostu (Meadows i in., 1973) byli atakowani za to, że nie biorą pod uwagę innowacji technologicznych i kreatywności człowieka, które pozwolą nam przecież przekraczać kolejne ograniczenia (Bonneuil, Fressoz, 2016, s. 217). Idea nieograniczonego wzrostu PKB wiąże się z ideami takimi jak wycena usług ekosystemowych, podatki korygujące degradację, handel limitami zanieczyszczeń. Pozwalają nam one ująć przyrodę jako „największy biznes na świecie”. Nawet zasada „zanieczyszczający płaci” legitymizuje degradację środowiska. Idea kompensacji szkód środowiskowych wpisuje się przecież w logikę rynkową (Bonneuil, Fressoz, 2016, ss. 219, 221).

${ }^{17}$ Zarządzanie lasami w Niemczech regulował traktat z 1713 roku. Pewne zasady dotyczące racjonalnego korzystania z lasów wprowadzały już umowy średniowieczne. 
Nie sposób oddzielić historii kolonializmu, niewolnictwa, imperialnej eksploatacji, podtrzymywania niedorozwoju i zależności krajów trzeciego świata od procesów, które doprowadziły do Wielkiego Przyspieszenia, a następnie planetarnego kryzysu środowiskowego. Z tych powodów część badaczy opowiada się za tym, by termin antropocenu zastąpić etykietką kapitalocenu. Bonneuil i Fressoz przekonują, że u źródeł obecnych problemów leżą wywodzące się z XVI wieku reżimy własności prywatnej i kapitalistyczna logika pogoni za zyskiem. Współczesny system bankowy nie rozwinąłby się, gdyby nie zapotrzebowanie na ubezpieczenia ryzykownych wypraw handlowych epoki kolonializmu. Metabolizm systemu kapitalistycznego był przy tym od początku skrajnie nieegalitarny, przede wszystkim ze względu na nierówną wymianę zasobów między centrum a peryferiami. Opowiada o tym wszystkim Kapitalocen kolejny, dziesiąty rozdział książki Szok antropocenu.

Francuscy historycy środowiska podkreślają, że to Imperium Brytyjskie narzuciło kapitalizm paliw kopalnych całemu światu (Bonneuil, Fressoz, 2016, s. 238). Imperium dążyło do obniżenia kosztów koordynacji na szeroką skalę. Inwestowano zatem $\mathrm{w}$ budowę kanałów transkontynentalnych, linii kolejowych, portów, doków, spichlerzy i linii telegraficznych. Kolonializm skutkował przy tym dezintegracją gospodarek przedkapitalistycznych w krajach trzeciego świata. Jak postulują autorzy recenzowanej rozprawy, refleksja dotycząca historii kapitalizmu musi uzupełniać namysł nauk o systemie Ziemi (Bonneuil, Fressoz, 2016, s. 252).

Wreszcie ostatni rozdział recenzowanej publikacji zatytułowany Polemocen to narracja ukazująca różnorodne oblicza oporu ubogich przeciwko degradacji planety. Od 1750 roku świadectwa tego typu oporu i „środowiskowego ruchu ubogich" znajdziemy zarówno w krajach centrum, jak i na peryferiach. Rzemieślnicy i robotnicy wiejscy występowali przeciwko mechanizacji produkcji i przeciwko właścicielom maszyn. Jednak opór przeciwko zmianom technologicznym nigdy nie był prymitywną technofobią, ale łączył się z walką o prawa tych grup społecznych, których kompetencje stawały się zbędne (Bonneuil, Fressoz, 2016, s. 261). Występowano przeciwko koncentracji kapitału i władzy w rękach właścicieli fabryk, przeciwko monopolizacji, przeciwko prywatyzowaniu lasów. Krytykowano kolej parową za to, że jest droższa niż transport konny czy rzeczny, a ubodzy mają do niej utrudniony dostęp. W XIX wieku składano tysiące petycji przeciwko fabrykom chemicznym ze względu na zagrożenia dla zdrowia populacji, kwaśne deszcze i zatruwanie jezior.

Jak wynika z argumentacji Bonneuila i Fressoz, zamiast mówić o narodzinach refleksyjności środowiskowej dzięki debacie na temat antropocenu, powinniśmy raczej pytać o to, jakim cudem owa wielka koalicja zielonego oporu uległa kapitalizmowi paliw kopalnych? Wielowymiarowe protesty i opór przeciwko degradacji planety udało się mimo wszystko skutecznie spychać na 
margines. Francuscy badacze podkreślają, że były to procesy historycznie przygodne (Bonneuil, Fressoz, 2016, s. 258).

Jak zatem widzimy, w ostatniej części swej książki Bonneuil i Fressoz proponują siedem alternatywnych narracji historycznych na temat tego, jakie dokładnie procesy przywiodły ludzkość do epoki antropocenu. To opowieści, które pobudzają wyobraźnię. Odsłaniają one przygodność wydarzeń, których byliśmy świadkami. Sprawy mogły potoczyć się inaczej (i wciąż jeszcze mogą). Nie jesteśmy skazani ani na obecny ład geopolityczny, ani na bieżący neoliberalny porządek ekonomiczny, ani na rozwiązania energetyczne kapitalizmu paliw kopalnych. Historia pomaga nam to sobie uświadomić. I to jest chyba najbardziej wartościowe przesłanie Szoku antropocenu.

\section{Bibliografia}

Angus, I. (2016). Facing the anthropocene: Fossil capitalism and the crisis of the Earth system. Nowy Jork, NY: Monthly Review Press.

Bińczyk, E. (2013). Problem sceptycyzmu wobec zmiany klimatycznej a postkonstruktywizm. Przegląd Kulturoznawczy, 1(15), 48-66.

Bińczyk, E. (2015). Monitorowanie technologii a nieusuwalne granice sterowalności (na przykładzie krytyki projektu inżynierii klimatu). Studia BAS - Biura Analiz Sejmowych, 3(43), 113-136.

Bonneuil, C., J.-B. Fressoz. (2016). The shock of the anthropocene: The Earth, history and us. (D. Fernbach, tłum.). Londyn, UK: Verso.

Brundtlandt, G. H. (1987). Our common future: Report of the world commission on environment and development. Oksford, UK: Oxford University Press.

Caradonna, J. et al. (2015). A degrowth response to an ecomodernist manifesto. http://www.resilience.org/articles/General/2015/05_May/A-Degrowth-Response-toAn-Ecomodernist-Manifesto.pdf. Dostęp 20.01.2018.

Crutzen, P., Stoermer, E. F. (2000). The 'anthropocene'. Global Change Newsletter, 41, $17-$ 18.

Fleming, J. R. (2010). Fixing the sky: The checkered history of weather and climate control. Nowy Jork, NY: Columbia University Press.

Hamilton, C., Bonneuil, C., Gemenne, F. (red.). (2015). The anthropocene and the global environmental crisis: Rethinking modernity in a new epoch. Londyn, UK: Routledge.

Hamilton, C. (2017). Defiant Earth: The fate of humans in the anthropocene. Cambridge Malden, MA: Polity Press.

Heede, R. (2014). Tracing anthropogenic carbon dioxide and methane emissions to fossil fuel and cement producers, 1854-2010. Climatic Change, 122(1-2): 229-241.

Jackson, T. (2015). Dobrobyt bez wzrostu: Ekonomia dla planety o ograniczonych możliwościach. (M. Polakowski, przeł). Toruń: Wydawnictwo Naukowe UMK. 
Meadows, D. et al. (1973). Granice wzrostu. (W. Rączkowska, S. Rączkowski, tłum.). Warszawa: Państwowe Wydawnictwo Ekonomiczne.

Moore, J. W. (red.). (2016). Anthropocene or capitalocene? Nature, history, and the crisis of capitalism. Oakland, CA: PM Press.

Olson, V., L. Messeri. (2015). Beyond the anthropocene. Un-Earthing an epoch. Environment and Society: Advances in Research, 6: 28-47.

Oreskes, N., Conway, E. M. (2010). Merchants of doubt: How a handful of scientists obscured the truth on issues from tobacco smoke to global warming. Nowy Jork, NY: Bloomsbury Press.

Rockström, J. et al. (2009). A safe operating space for humanity. Nature, 46, 472-475.

Steffen, W., Grinevald, J., Crutzen, P., McNeill, J. R. (2011). The anthropocene: Conceptual and historical perspectives. Philosophical Transactions of the Royal Society. Series A, 369(1938), 842-867.

Steffen, W., P. Crutzen, J. R. McNeill. (2007). The anthropocene: Are humans now overwhelming the great forces of nature? Ambio, 36(8), 614-621.

Stengers, I. (2009). Au Temps des catastrophes. Paryż: Les Empêcheurs de penser au rond/La découverte.

\title{
The Shock of the Anthropocene. A book review
}

\begin{abstract}
This book is in many aspect a unique publication, clearly worth noticing. It is an element of a decade-long intense debate on the Anthropocene in which the participants are the representatives of both natural sciences and humanities. The discussion has extremely interesting philosophical overtone as it uncovers multiple paradoxes. Primarily, the events which lead the scholars to calling this new geological period Anthropocene are a testimony both to human power and hyper-agency and to multidimensional helplessness and powerlessness. This is excellently highlighted by the reviewed monograph.
\end{abstract}

Keywords: Anthropocene; Earth; environmental history 